\title{
Late Pleistocene glaciers and climate in the Mediterranean
}

\author{
P.D. Hughes ${ }^{\mathrm{a}, *}$, J.C. Woodward ${ }^{\mathrm{a}}$, P.L. Gibbard ${ }^{\mathrm{b}}$ \\ a Geography, Mansfield Cooper Building, School of Environment and Development, The University of Manchester, \\ Oxford Road, Manchester M13 9PL, United Kingdom \\ ${ }^{\mathrm{b}}$ Godwin Institute of Quaternary Research, Department of Geography, University of Cambridge, Downing Place, \\ Cambridge CB2 3EN, United Kingdom
}

Received 3 March 2005; accepted 14 July 2005

Available online 25 January 2006

\begin{abstract}
Evidence for Late Pleistocene glaciers and rock glaciers in the Pindus Mountains, Greece, is used to reconstruct palaeoclimate for this part of the Mediterranean during the last cold stage (Tymphian/ Würmian). Mean annual precipitation was $c$. $2300 \pm 200$ $\mathrm{mm}$ and the mean summer temperature (June/July/August) was $c .4 .9^{\circ} \mathrm{C}$ at $2174 \mathrm{~m}$ a.s.1., the equilibrium line altitude of the former glaciers, at the last local glacier maximum. The glacier-climate relationship in the northern Pindus Mountains during the local glacier maximum of the Tymphian Stage closely resembled that found today at the equilibrium line altitude of Norwegian glaciers. The local glacier maximum on Mount Tymphi is likely to have preceded both the most severe phase of climate indicated in the pollen record at nearby Ioannina and also the global last glacial maximum. Major stadials, including the most severe phase of the last cold stage, were characterised by cold sea surfaces temperatures, which inhibited atmospheric moisture supply creating unfavourable conditions for glacier formation. Such stadial conditions are likely to have favoured periglacial conditions and the formation of features such as rock glaciers. Conversely, warm summer temperatures during major interstadials would have promoted glacier ablation, offsetting increased precipitation enabled by warmer sea surface temperatures. Thus, the most favourable conditions for glacier formation would have occurred during intermediate conditions between major stadials and interstadials. It is clear that former glacier behaviour in the mountains of this region is best understood with reference to temporally dynamic glacier-climate models, which take into account millennial-scale changes in both precipitation and temperature.
\end{abstract}

(C) 2005 Elsevier B.V. All rights reserved.

Keywords: Pleistocene; Palaeoclimate; glaciation; Pindus Mountains; Greece; Würmian; Tymphian

\section{Introduction}

The Pindus Mountains of Greece were glaciated on numerous occasions during the Pleistocene. Glacial landforms and sediments are widely preserved and the timing of glaciation has been constrained through the uranium-series (U-series) dating of cemented glacial deposits (Woodward et al., 2004;

\footnotetext{
* Corresponding author.

E-mail address: philip.hughes@man.ac.uk (P.D. Hughes).
}

Hughes, 2004). The earliest recorded glaciation occurred over 350,000 years ago during the Middle Pleistocene. This glaciation has been correlated with the Elsterian glaciation in northern Europe and marine isotope stage (MIS) 12. A second glaciation occurred prior to the last (Eemian) interglacial and has been correlated with part of the Saalian Stage of northern Europe and MIS 6. The most recent phase of glaciation occurred during the last glacial stage when cirque glaciers and periglacial rock glaciers formed (Hughes et al., 2003). 
The glacial and periglacial record in the Mediterranean region offers considerable potential for palaeoclimatic research, since it is well established that glaciers and periglacial activity have a close relationship with climate (e.g., Ohmura et al., 1992; Barsch, 1996). Previous palaeoclimatic research in Greece has largely relied on evidence from palaeoecological data from lacustrine sequences. For example, Peyron et al. (1998) reconstructed palaeotemperature and palaeoprecipitation values for the global last glacial maximum in Greece and southern Europe using pollen evidence. In addition, the pollen record from a 423,000-year continuous lacustrine sequence at Ioannina in Epirus has provided detailed insights into vegetation dynamics through glacial-interglacial cycles (Tzedakis, 1993, 1994). However, whilst these records provide long term indirect evidence of regional moisture supply, they are limited in their capacity to provide the basis for precise reconstructions of atmospheric temperatures and temperatureprecipitation combinations.

The evidence from long pollen sequences in the Mediterranean region suggest significantly reduced moisture supply compared to present-day conditions during the most severe parts of cold stages, based on the high frequency of non-arboreal pollen compared to arboreal pollen (Willis, 1994; Allen et al., 2000). However, at Ioannina (483 m a.s.1.), a mid-altitude site in the Pindus Mountains, whilst tree populations appear to have been much reduced during glacial phases compared with interglacials, even deciduous species were sustained through multiple glacial cycles (Tzedakis, 1993). This was not the case in lower altitude areas in eastern and central Greece (Tzedakis, 1999; Tzedakis et al., 2003) where precipitation was too low to support such trees.

Although moisture supply appears to have been sufficient to sustain tree populations through glacial cycles at Ioannina, during the last cold stage, global circulation modelling suggests that precipitation in Greece was depressed by over 50\% compared to the present (Pollard and Barron, 2003; Tzedakis et al., 2002). A similar precipitation depression was also suggested by Peyron et al. (1998) using a pollen-based model based on a best analogues approach. In addition, Peyron et al. (1998, Fig. 5b) estimated that mean annual temperatures were $8-9{ }^{\circ} \mathrm{C}$ lower than present values for the height of the last cold stage at three sites in the Pindus Mountains area-although the error range for these estimates was c. $6-8{ }^{\circ} \mathrm{C}$. A separate independent palaeoclimate model has yielded estimates of mean winter and summer depressions for the last glacial maximum of 10 and $6.8{ }^{\circ} \mathrm{C}$, respectively (Tzedakis et al., 2002; Pollard and Barron, 2003) and, combined with simulated precipitation values (see above), is broadly consistent with ecological models for pollen sites around Greece (Tzedakis et al., 2004).

An important characteristic of glacial stage environments in Greece is the dynamic nature of vegetation change in response to millennial-scale climatic change (Tzedakis et al., 2004). Changes in arboreal pollen frequencies at Ioannina appear to correspond with millennial scale change indicated in both the Greenland ice core isotope record ( $c f$. Dansgaard et al., 1993) and in the alkenone-derived sea surface temperatures in the Mediterranean Sea (cf. Cacho et al., 1999; Sánchez Goñi et al., 2002). Colder sea surface temperatures in the Mediterranean during the last cold stage appear to have been closely related to Heinrich Events in the North Atlantic, when polar waters entered the Mediterranean Sea through the Straits of Gibraltar (Cacho et al., 1999). The effects of such incursions appear to have penetrated throughout the Mediterranean Sea. For example, evidence from the southern Aegean Sea suggests that short term climate changes in this area over the last 48,000 years are closely associated with events in the North Atlantic region (Geraga et al., 2005). In fact, many climate events recorded in the North Atlantic have also been recognised in terrestrial (speleothem and lakelevel) records as far east as Israel (Bar-Matthews et al., 1999; Bartov et al., 2003). Thus the sensitivity of the Mediterranean Sea and surrounding regions to events in the North Atlantic Ocean is well established (Allen et al., 1999). Cooler sea surface temperatures during Heinrich events and Dansgaard-Oeschger stadials would have inhibited moisture supply to the atmosphere leading to a decline in precipitation. This response is reflected in pronounced reductions in arboreal pollen frequencies in western Greece during these periods (Tzedakis et al., 2004).

Against this background, this paper has three principal aims: 1) to use glacial and periglacial evidence to reconstruct temperature-precipitation combinations in the Pindus Mountains for the last cold stage; 2) to examine potential climate conditions for glacier formation with reference to the high resolution pollen record for the last cold stage at sites such as Ioannina (Tzedakis et al., 2002, 2004); and, 3) to understand the behaviour of mountain glaciers in Greece during the last cold stage within a dynamic model integrating records of vegetation change, sea surface temperatures in the Mediterranean and ice-ocean dynamics in the North Atlantic. 


\section{Study area}

This paper is based on glacial and periglacial evidence found on Mount Tymphi (2497 m a.s.1.) and Mount Smolikas (2637 m a.s.1.) in Epirus, northwest Greece (Fig. 1). Mount Tymphi comprises a series of uplifted fault blocks and faulted escarpments and is formed largely in Palaeocene-Eocene limestone, with some exposures of Senonian-Jurassic dolomites and limestones on the northern scarp and in the Vikos Gorge to the south (IGME, 1970). The lower slopes are dominated by younger flysch rocks of Late Eocene to Miocene age. Mount Smolikas, the highest peak of the Pindus Mountains and $c .15 \mathrm{~km}$ to the northeast of Mount Tymphi, is formed in ultrabasic and basic ophiolitic rocks which include lithologies such as serpentinite, dunite and harzburgites (IGME, 1987). Jurassic limestones and schists are also present in localised areas.

Climate in the mountains is cool and wet with mean summer and winter temperatures of less than 15 and $5{ }^{\circ} \mathrm{C}$, respectively (Furlan, 1977). Precipitation in this area is strongly controlled by elevation and by distance from the coast and mean annual precipitation values of up to $2550 \mathrm{~mm}$ have been recorded in the central Pindus range (Fotiadi et al., 1999). At Skamnelli (1180 m a.s.1.), on the southern slopes of Mount Tymphi, and the highest meterological station in this area, mean annual precipitation is $1721 \mathrm{~mm}$ (Fotiadi et al., 1999). However, no records exist for the highest mountain areas $(>2000 \mathrm{~m}$ a.s.1.), although precipitation is probably well over 2000 mm (Furlan, 1977).

\section{Glacial and periglacial evidence}

Detailed field survey incorporating glacial and periglacial geomorphological mapping was undertaken over 12 weeks between 2001 and 2004. To develop a robust geochronology for the glacial record on Mount Tymphi, cemented glacial units were dated using the Useries method (cf. Woodward et al., 2004) and soil development on moraine surfaces was quantified to provide an additional correlation tool (Hughes, 2004). The glacial and periglacial sequence on neighbouring Mount Smolikas was correlated with that on Mount Tymphi based on morphostratigraphy, supported by correlations using reconstructed glacier equilibrium line altitudes (ELAs) (see below). The glacial and periglacial

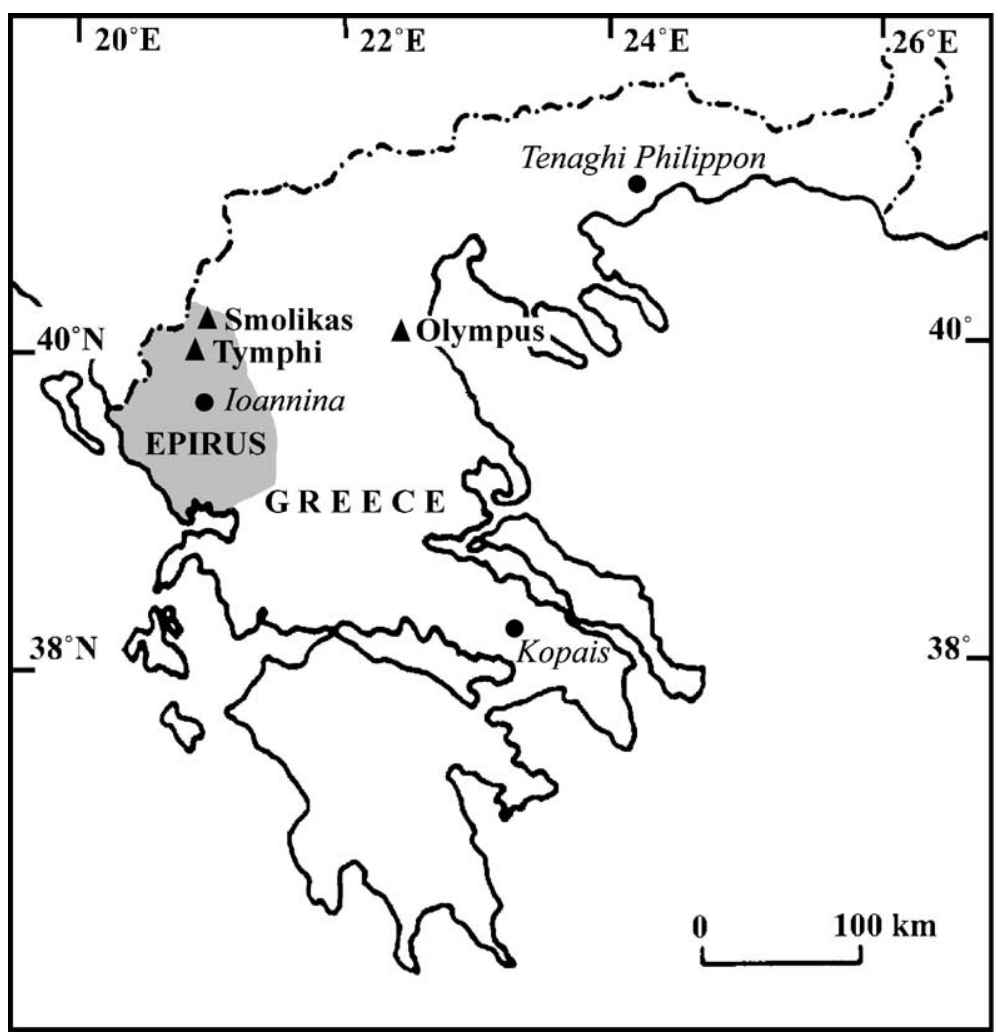

Fig. 1. Location map showing the field areas in relation to Mount Olympus and the major pollen sites of Ioannina, Tenaghi Philippon and Kopais. 
sequence in the northern Pindus was then anchored to the nearby 423,000 year-long pollen stratigraphy from the lacustrine sequence at Ioannina (which acted as a parastratotype) enabling the development of a chronostratigraphy for glacial stages in the region (Fig. 2) (Hughes et al., 2005). The oldest glacial stage, termed the Skamnellian Stage after a village in the type area, took place before 350,000 years $\mathrm{BP}$ and is defined as the cold stage immediately prior to the base of the Dodoni Interglacial at Ioannina ( $c f$. Tzedakis, 1994). This stage is correlated with the Elsterian Stage of northern Europe and MIS 12 (Hughes, 2004; Hughes et al., 2005). The next youngest glacial stage, named the Vlasian Stage after a mountain close to the type area, is defined as the

\begin{tabular}{|c|c|c|c|c|c|}
\hline $\begin{array}{l}\text { Age } \\
(x 1,000 \text { years })\end{array}$ & MIS & $\begin{array}{l}\text { Ioannina } \\
\text { (IN 249/284) }\end{array}$ & $\begin{array}{l}\text { Para- } \\
\text { stratotype } \\
\text { boundary } \\
\text { (IN 249) }\end{array}$ & $\begin{array}{l}\text { Pindus } \\
\text { Chrono- } \\
\text { stratigraphy }\end{array}$ & Local Stratotype \\
\hline $11.5-$ & 1 & Holocene & $17.25 \mathrm{~m}$ & & \\
\hline \multirow{3}{*}{$73.9-11.5$} & 2 & & \multirow[b]{7}{*}{$45.88 \mathrm{~m}$} & \multirow{7}{*}{ Tymphian } & \multirow{7}{*}{$\begin{array}{l}\text { Tsouka Rossa Member } \\
39^{\circ} 58^{\circ} 45^{\prime \prime N}, 20^{\circ} 50^{\prime} 40^{\prime \prime} \mathrm{E}, 2025 \mathrm{~m} \text { a.s.l. }\end{array}$} \\
\hline & 3 & & & & \\
\hline & 4 & & & & \\
\hline $73.9-83.0 *$ & $5 a$ & Interstadial $2^{\S}$ & & & \\
\hline $88.5^{*}-83.0^{*}$ & $5 b$ & Stadial $2^{\S}$ & & & \\
\hline $104.5^{*}-88.5^{*}$ & $5 c$ & Interstadial $1^{\S}$ & & & \\
\hline $111.0^{*}-104.5^{*}$ & $5 d$ & Stadial $1^{\S}$ & & & \\
\hline $126.6^{*}-111.0^{*}$ & $5 e$ & Metsovon & $59.00 \mathrm{~m}$ & & \\
\hline $189.6-126.6 *$ & 6 & & $76.00 \mathrm{~m}$ & $\begin{array}{l}\text { Vlasian } \\
\text { Stage }\end{array}$ & $\begin{array}{l}\text { Vourtapa Member } \\
39^{\circ} 55^{\prime} 50^{\prime \prime} \mathrm{N}, 20^{\circ} 51^{\prime} 10^{\prime \prime} \mathrm{E}, 1650 \mathrm{~m} \text { a.s.l. }\end{array}$ \\
\hline $244.2-189.9$ & $7 a-e$ & $\begin{array}{l}\text { IN-26 } \\
\text { Zitsa } \\
\text { IN-23a }\end{array}$ & & \multirow{4}{*}{$?$} & \\
\hline $303-244.2$ & 8 & & & & \\
\hline $339-303$ & $9 a-e$ & $\begin{array}{l}\text { Katara } \\
\text { IN-17 } \\
\text { Pamvotis }\end{array}$ & & & \\
\hline $362-339$ & 10 & & & & \\
\hline $423-362$ & 11 & Dodoni I / II & $162.75 \mathrm{~m}$ & & \\
\hline $478-423$ & 12 & & $184.00 \mathrm{~m}$ & $\begin{array}{c}\text { Skamnellian } \\
\text { Stage }\end{array}$ & $\begin{array}{l}\text { Kato Radza Member } \\
39^{\circ} 54^{\prime} 08^{\prime \prime} \mathrm{N}, 20^{\circ} 50^{\prime} 40^{\prime \prime} \text { E. } 984 \text { m a.s.l. }\end{array}$ \\
\hline
\end{tabular}

Fig. 2. Correlation table showing the relationship between the fragmentary glacial and periglacial sequence in the Pindus Mountains, Greece, and the continuous lacustrine parasequence in the nearby Ioannina 249 and 284 cores ( $c f$. Tzedakis, 1994; Tzedakis et al., 2002). MIS=Marine Isotope Stage. $\S=$ Names based on Tzedakis et al. (2002) —all other names for the Ioannina sequence are from Tzedakis (1994). * Interval dates from Tzedakis et al. (2002) — all other dates from orbitally tuned marine isotope records (Imbrie et al., 1984; Martinson et al., 1987). 
cold stage between the top of the Zitsa and the base of the Metsovon Interglacials at Ioannina. This stage is correlated with the upper part of the Saalian Stage in northern Europe and equated with MIS 6 (Hughes, 2004; Hughes et al., 2005). The most recent glacial stage, named the Tymphian after Mount Tymphi where type deposits are best represented, is defined as the interval between the top of the Metsovon Interglacial and the base of the Holocene. This stage is correlated with the Würmian of the Alps and the Weichselian in northern Europe, which are correlated with MIS 5d-2. The glaciers that formed during the Tymphian Stage and the palaeoclimatic conditions that produced them are the focus of this paper.

\section{Glacier reconstruction}

Palaeo-glaciers in the region were reconstructed based on the geomorphological and sedimentological evidence following standard procedures (Sissons, 1974; Ballantyne, 1989). Equilibrium line altitudes were reconstructed using the accumulation area ratio (AAR) method. An AAR value of 0.6 was applied to the reconstructed glaciers (cf. Porter, 1975; Nesje and Dahl, 2000). Given the small size and limited altitudinal distribution of the Tymphian glaciers (Table 1), the consequences of any disparity between the assumed and actual AAR are unlikely to be significant.

The main features of the Tymphian Stage glaciers and rock glaciers on Mount Tymphi and Mount Smolikas are shown in Table 1 and illustrated in Figs. 3 and 4. The last glaciers of Mount Tymphi covered an area of c. $3.90 \mathrm{~km}^{2}$ and had a mean ELA of $2174 \mathrm{~m}$ a.s.1. Only two of the glaciers, the Laccos Tselon and the Laccos Megalon Litharion glaciers, had areas greater than $1 \mathrm{~km}^{2}$ (Fig. 3). Rock glaciers formed below the Tsouka Rossa cirque glaciers and in several cirques not occupied by glaciers. The six rock glaciers reached a lower altitudinal limit of $1800 \mathrm{~m}$ a.s.l. The longest rock glacier was the Karteros rock glacier with a length of $c$. $725 \mathrm{~m}$, whilst the largest was the Tsouka Rossa debris rock glacier which covered an area of $0.53 \mathrm{~km}^{2}$ (Fig. 3). Perennial snow patches would also have existed in favourable localities and relict pronival ramparts are present in several areas (Hughes, 2004).

On Mount Smolikas, five glaciers covered an area of c. $2.55 \mathrm{~km}^{2}$ with a mean ELA of $2241 \mathrm{~m}$ a.s.l. during the glacier maximum of the Tymphian. The largest glacier, the Cirque $3 / 4$ glacier, covered an area of $c .1 .12 \mathrm{~km}^{2}$. These glaciers occupied the northern cirques of the main ridge and the eastern cirques of Moasa (Fig. 4). In contrast to Mount Tymphi, rock glacier formation was
Table 1

Tymphian glacier and rock glacier characteristics on Mount Tymphi and Mount Smolikas

\begin{tabular}{|c|c|c|c|}
\hline Mount Tymphi glaciers & $\begin{array}{l}\text { Area } \\
\left(\mathrm{km}^{2}\right)\end{array}$ & \multicolumn{2}{|l|}{$\begin{array}{l}\text { ELA } \\
\text { (metres a.s.1. ) }\end{array}$} \\
\hline $\begin{array}{l}\text { Laccos Megalon } \\
\text { Litharion }\end{array}$ & 1.11 & \multicolumn{2}{|l|}{2100} \\
\hline Laccos Tselon & 1.55 & \multicolumn{2}{|l|}{2175} \\
\hline Tsouka Rossa 1 & 0.21 & \multicolumn{2}{|l|}{2180} \\
\hline Tsouka Rossa 2 & 0.35 & \multicolumn{2}{|l|}{2200} \\
\hline Tsouka Rossa 3 & 0.55 & \multicolumn{2}{|l|}{2215} \\
\hline Tsouka Rossa 4 & 0.13 & \multicolumn{2}{|l|}{2175} \\
\hline & Total area: & \multicolumn{2}{|c|}{ Mean ELA: 2174} \\
\hline $\begin{array}{l}\text { Mount Tymphi } \\
\text { rock glaciers }\end{array}$ & $\begin{array}{l}\text { Area } \\
\left(\mathrm{km}^{2}\right)\end{array}$ & $\begin{array}{l}\text { Length } \\
\text { (metres) }\end{array}$ & $\begin{array}{l}\text { Front altitude } \\
\text { (metres a.s.1.) }\end{array}$ \\
\hline Tsouka Rossa & 0.53 & 690 & 2000 \\
\hline Karteros & 0.35 & 725 & 2000 \\
\hline Kopanes & 0.39 & 650 & 1900 \\
\hline Gamila & 0.08 & 400 & 1950 \\
\hline Amarandos & 0.12 & 480 & 1800 \\
\hline \multirow[t]{3}{*}{ Vlasi } & 0.14 & 300 & 1850 \\
\hline & Total area: & Mean length: & Lowest front: \\
\hline & 1.61 & 541 & 1800 \\
\hline $\begin{array}{l}\text { Mount Smolikas } \\
\text { glaciers }\end{array}$ & $\begin{array}{l}\text { Area } \\
\left(\mathrm{km}^{2}\right)\end{array}$ & \multicolumn{2}{|l|}{$\begin{array}{l}\text { ELA } \\
\text { (metres a.s.l. ) }\end{array}$} \\
\hline Cirque 1 & 0.25 & \multicolumn{2}{|l|}{2125} \\
\hline Cirque 2 & 0.21 & \multicolumn{2}{|l|}{2340} \\
\hline Cirque $3 / 4$ & 1.12 & \multicolumn{2}{|l|}{2340} \\
\hline Galanos Limni & 0.69 & \multicolumn{2}{|l|}{2180} \\
\hline Southeast Moasa & 0.28 & \multicolumn{2}{|l|}{2220} \\
\hline & $\begin{array}{l}\text { Total area: } \\
2.55\end{array}$ & \multicolumn{2}{|c|}{ Mean ELA: 2241} \\
\hline
\end{tabular}

not widespread on Mount Smolikas during the Tymphian. However, a rock glacier did form at higher altitudes than the Mount Tymphi rock glaciers during a later cold phase. This rock glacier formed in the Northwestern Cirque (Fig. 4) and may in fact obscure evidence of earlier glacier formation during the Tymphian glacier maximum. This rock glacier, together with several cirque glaciers with higher ELAs than during the Tymphian glacier maximum, formed during the Late-glacial and possibly during an interval equivalent to the Younger Dryas (Hughes et al., in press-a).

\section{Palaeoclimate reconstruction-methods}

Glaciers have a sensitive relationship with climate. The two most important climatic variables are temperature and precipitation and, in modern glacial environments, it is well established that a positive relationship exists between these variables. This is because higher 


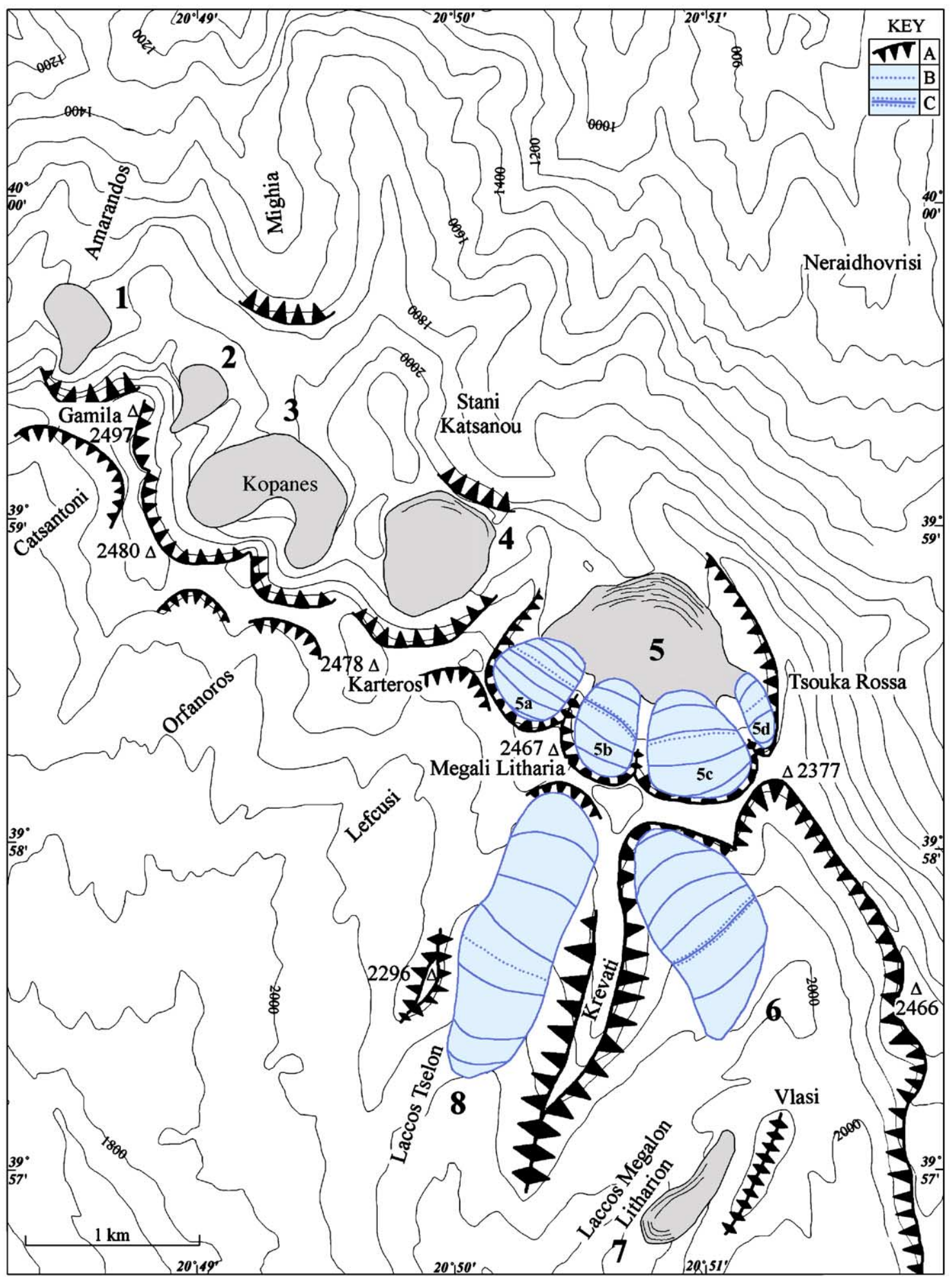

Fig. 3. The Mount Tymphi glaciers and rock glaciers during the Tymphian glacial maximum. 1: Amarandos rock glacier. 2: Gamila rock glacier. 3: Kopanes rock glacier. 4: Karteros rock glacier. 5: Tsouka Rossa rock glacier (5a-d: Tsouka Rossa glaciers 1-4 respectively). 6: Laccos Megalon Litharion glacier. 7: Vlasi rock glacier. 8: Laccos Tselon glacier. Glaciers are contoured at $50 \mathrm{~m}$ intervals (land contours at $100 \mathrm{~m}$ intervals). Key: A: Steep cliffs of glacier source areas (including pre-Tymphian glaciations); B: equilibrium line; C: equilibrium line coinciding with $50 \mathrm{~m}$ contour. 


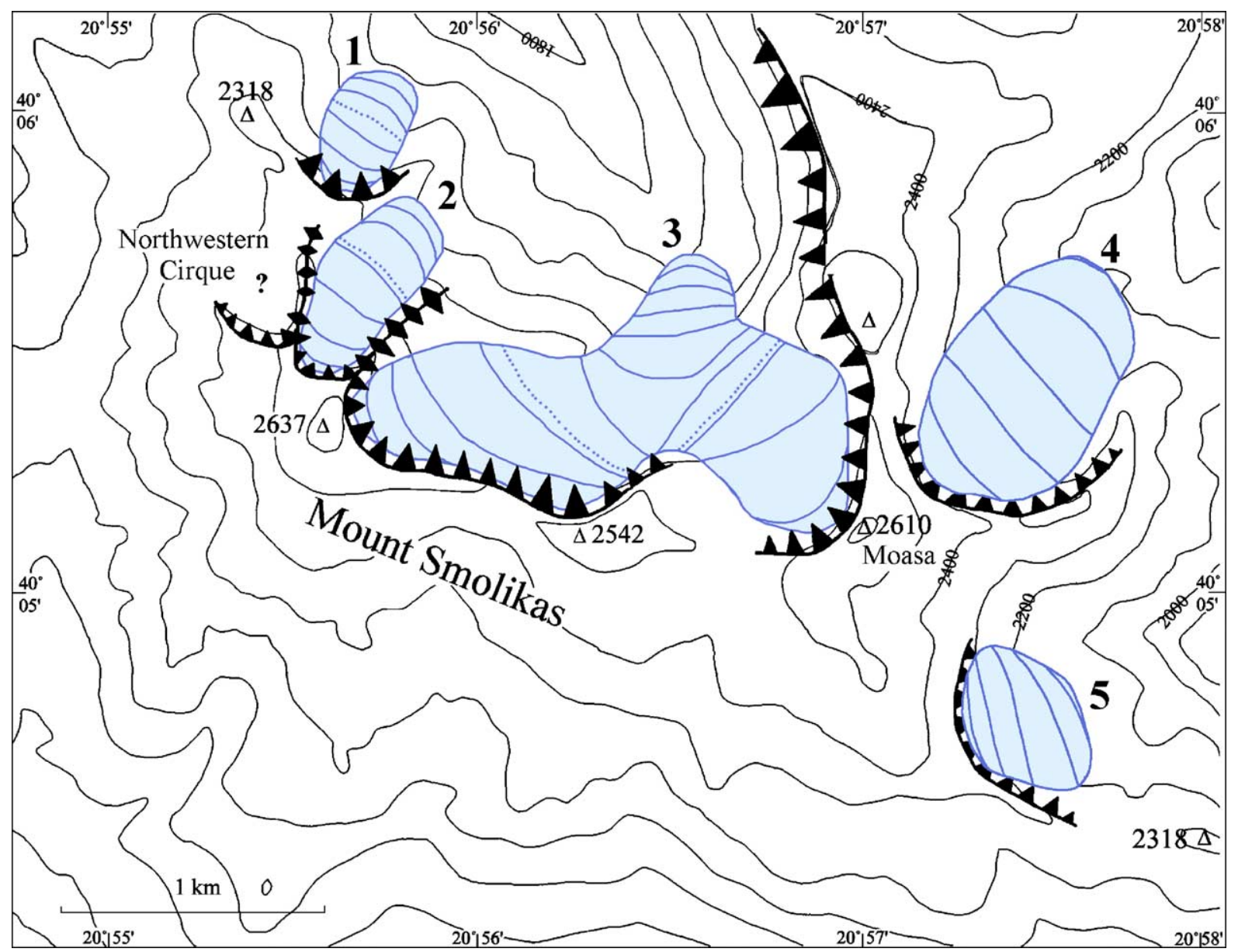

Fig. 4. The Smolikas glaciers during the Tymphian glacial maximum. 1: Cirque 1 glacier. 2: Cirque 2 glacier. 3: Cirque 3/4 glacier. 4: Galanos Limni glacier. 5: Southeast Moasa glacier. Glaciers are contoured at $50 \mathrm{~m}$ intervals (land contours at $100 \mathrm{~m}$ intervals). The key is the same as for Fig. 3.

levels of mass turnover at the ELA require higher ablation, and thus higher summer temperatures to balance the mass budget (Ahlmann, 1948; Loewe, 1971; Ballantyne, 1989; Ohmura et al., 1992). The form of this relationship appears to have global application (Nesje and Dahl, 2000). The regression of Ohmura et al., (1992), derived from 70 glaciers worldwide, is used in this study. The relationship between annual precipitation and mean summer (June/July/August) temperature at the ELA corresponds to the following polynomial regression curve:

$P=a+b T+c T^{2}$.

Where $a=645, b=296$ and $c=9$, and $P$ and $T$ are mean annual precipitation $(\mathrm{mm})$ and mean summer temperatures $\left({ }^{\circ} \mathrm{C}\right)$ respectively. The standard error for this curve is relatively narrow at $200 \mathrm{~mm}$ and can be explained as being largely a result of different radiation conditions (Ohmura et al., 1992).

The Ohmura et al. (1992) equation represents the relationship between mean annual precipitation and temperature rather than just winter accumulation and temperature. After comparing precipitation and accumulation at glacier ELAs around the world, Ohmura et al. (1992) concluded that the winter mass balance (accumulation) comes very close to the mean annual meteorological precipitation on a number of glaciers. They therefore argued that this justified the approximation of the annual precipitation using the winter mass balance. It is important to appreciate, however, that discrepancies arise where local inputs, such as wind-blown snow and avalanche accumulation, are a major component of the mass balance. In such circumstances, the precipitation value derived will be higher than the true meteorological annual precipitation. However, for any reconstructed glacier within a 
sample, major local inputs will be recognised as a consequence of a lower ELA relative to the mean.

Using the Ohmura et al. (1992) equation, for any reconstructed former glacier, the possible combinations of temperature and precipitation, at the time of maximal extent, can be deduced. However, in order to determine which of these combinations applied to the Late Pleistocene glaciers in Greece, values for either palaeoprecipitation or palaeotemperature are required. Either input can be derived from other contemporaneous evidence, such as that from climatic models based on independent evidence (e.g., Peyron et al., 1998; Pollard and Barron, 2003) or from associated evidence in the periglacial record, such as rock glaciers (e.g., Hughes et al., 2003).

In common with glaciers, periglacial rock glaciers are highly sensitive to climate. It is well established that rock glaciers form in areas of discontinuous permafrost, where mean annual temperatures are no higher than $c .-2{ }^{\circ} \mathrm{C}$. This has been demonstrated in a wide range of mountain environments, including the Swiss and Italian Alps (Barsch, 1978; Fisch et al., 1977; Belloni et al., 1988; Carton et al., 1988), as well as in the New Zealand Alps (Brazier et al., 1998). Rock glaciers will form at temperatures much lower than $-2{ }^{\circ} \mathrm{C}$ but only where precipitation is sufficiently low to inhibit glacier formation (Haeberli, 1982, 1985; Barsch, 1996). Rock glaciers would therefore be expected to form below the regional glacier ELA. However, they may form above the regional glacier ELA because rock glacier formation also depends on debris supply exceeding snow accumulation (Humlum, 1998). This implies that even where precipitation is adequate for glacier formation, if debris supply is sufficiently large, a rock glacier will form instead. Nevertheless, in any given region it is likely that the lowest occurrence of rock glaciers will lie close to the limit of permafrost. In areas where this is much lower than the highest mountains, a wide range of rock glacier altitudes may exist contemporaneously. Where the lower limit of discontinuous permafrost lies close to the highest parts of a mountain, rock glacier fronts will often have low altitudinal variation since there is simply not the space to accommodate rock glaciers in areas above the $-2{ }^{\circ} \mathrm{C}$ isotherm. In some cases, rock glaciers may not always occur at the lower limit of the permafrost boundary and may not form at all. Their formation will depend on local debris supply and topographic conditions. However, where there is a strong concentration of rock glaciers at a particular altitude, it is likely to be related to the lower limit of the permafrost boundary and the $-2{ }^{\circ} \mathrm{C}$ isotherm.

\section{Palaeoclimate reconstruction-results}

Palaeotemperatures for the Tymphian can be estimated from the rock glacier evidence on Mount Tymphi. Hughes et al. (2003) argued that the lower limit of these rock glaciers (c. $1800 \mathrm{~m}$ a.s.l.) was likely to coincide with the lower limit of discontinuous permafrost and the $-2{ }^{\circ} \mathrm{C}$ mean annual isotherm. Given that the modern mean annual temperature is $14.4^{\circ} \mathrm{C}$ at Ioannina (484 m a.s.1.) (based on the 1951-1981 mean) and a lapse rate of $0.6{ }^{\circ} \mathrm{C}$ per $100 \mathrm{~m}$ altitude, this implies that mean annual temperatures were $c .8 .5^{\circ} \mathrm{C}\left[8-9{ }^{\circ} \mathrm{C}\right]$ lower than today at the time of rock glacier formation (Hughes et al., 2003).

In order to understand climate at the ELA of the former glaciers, the mean annual temperature of $-2{ }^{\circ} \mathrm{C}$ at the foot of the former rock glaciers (c. $1800 \mathrm{~m}$ a.s.1.) was extrapolated to the mean ELA of nearby glaciers (2174 m a.s.l.) using a standard atmospheric lapse rate of $0.6{ }^{\circ} \mathrm{C}$ per $100 \mathrm{~m}$. The derived temperature of $-4.2{ }^{\circ} \mathrm{C}$ at $2174 \mathrm{~m}$ a.s.1. was then distributed over mean annual ranges of 10 to $30{ }^{\circ} \mathrm{C}$ on a sinusoidal mean monthly temperature curve. The derived mean summer temperature (June/July/August) and associated annual precipitation combination based on the relationship defined in Ohmura et al. (1992) is shown in Table 2.

A mean annual temperature of $-4.2{ }^{\circ} \mathrm{C}$ at the mean ELA of the former cirque glaciers (2174 $\mathrm{m}$ a.s.1.), distributed over an annual mean monthly temperature range of $20^{\circ} \mathrm{C}$, produces a mean summer temperature of $4.9^{\circ} \mathrm{C}$. Based on the equation of Ohmura et al. (1992), this summer temperature gives a mean annual precipitation of $2300 \pm 200 \mathrm{~mm}$ at $2174 \mathrm{~m}$ a.s.l. Precipitation at the range of the rock glaciers (c. $2100-1800 \mathrm{~m}$ a.s.l.) is likely to have been only slightly less. Thus, given that rock glaciers rarely form in areas where precipitation exceeds $2500 \mathrm{~mm}$ (Haeberli, 1985), the actual annual mean monthly temperature range is unlikely to have been significantly greater than $c .20^{\circ} \mathrm{C}$. A higher range produces higher summer temperatures and, as a result, implies precipitation well in excess of $2500 \mathrm{~mm}$ in the high cirques. A lower temperature range than today is unrealistic, particularly since the modern annual range of mean monthly temperatures is $c .20^{\circ} \mathrm{C}$ and the fact that during glaciation climate is likely to have been characterised by an annual range of mean monthly temperatures at least as great as today, especially when considering sea levels were $c$. 130-135 m lower ( $c f$. Yokoyama et al., 2000). The best compromise is, therefore, a palaeoprecipitation reconstruction derived under an annual temperature range of $20^{\circ} \mathrm{C}$. 
Table 2

Palaeoclimatic combinations reconstructed at the mean ELA of the last cirque glaciers on Mount Tymphi (2174 $\mathrm{m}$ a.s.1.). The values in bold represent the most likely combination for the glacial maximum of the Tymphian (see text for details). Annual precipitation was reconstructed using the equation of Ohmura et al. (1992). All temperature reconstructions are rounded up to 1 decimal place

\begin{tabular}{|c|c|c|c|c|c|}
\hline $\begin{array}{l}\text { Mean annual } \\
\text { temperature }\end{array}$ & Annual range & $\begin{array}{l}\text { Mean summer } \\
\text { temperature }\end{array}$ & $\begin{array}{l}\text { Coldest } \\
\text { month mean }\end{array}$ & $\begin{array}{l}\text { Warmest } \\
\text { month mean }\end{array}$ & $\begin{array}{l}\text { Annual } \\
\text { precipitation }\end{array}$ \\
\hline$-4.2^{\circ} \mathrm{C}$ & $30^{\circ} \mathrm{C}$ & $9.5^{\circ} \mathrm{C}$ & $-19.2{ }^{\circ} \mathrm{C}$ & $10.8^{\circ} \mathrm{C}$ & $4251 \mathrm{~mm}$ \\
\hline$-4.2^{\circ} \mathrm{C}$ & $27.5^{\circ} \mathrm{C}$ & $8.3^{\circ} \mathrm{C}$ & $-18.0^{\circ} \mathrm{C}$ & $9.5^{\circ} \mathrm{C}$ & $3717 \mathrm{~mm}$ \\
\hline$-4.2^{\circ} \mathrm{C}$ & $25^{\circ} \mathrm{C}$ & $7.2^{\circ} \mathrm{C}$ & $-16.7^{\circ} \mathrm{C}$ & $8.3^{\circ} \mathrm{C}$ & $3234 \mathrm{~mm}$ \\
\hline$-4.2^{\circ} \mathrm{C}$ & $22.5^{\circ} \mathrm{C}$ & $6.0^{\circ} \mathrm{C}$ & $-15.5^{\circ} \mathrm{C}$ & $7.0^{\circ} \mathrm{C}$ & $2745 \mathrm{~mm}$ \\
\hline$-4.2^{\circ} \mathrm{C}$ & $20^{\circ} \mathrm{C}$ & $4.9^{\circ} \mathrm{C}$ & $-14.2^{\circ} \mathrm{C}$ & $5.8^{\circ} \mathrm{C}$ & $2300 \mathrm{~mm}$ \\
\hline$-4.2^{\circ} \mathrm{C}$ & $17.5^{\circ} \mathrm{C}$ & $3.8^{\circ} \mathrm{C}$ & $-13.0^{\circ} \mathrm{C}$ & $4.6^{\circ} \mathrm{C}$ & $1889 \mathrm{~mm}$ \\
\hline$-4.2^{\circ} \mathrm{C}$ & $15^{\circ} \mathrm{C}$ & $2.6{ }^{\circ} \mathrm{C}$ & $-11.7^{\circ} \mathrm{C}$ & $3.3^{\circ} \mathrm{C}$ & $1486 \mathrm{~mm}$ \\
\hline$-4.2^{\circ} \mathrm{C}$ & $12.5^{\circ} \mathrm{C}$ & $1.5^{\circ} \mathrm{C}$ & $-10.5^{\circ} \mathrm{C}$ & $2.1^{\circ} \mathrm{C}$ & $1106 \mathrm{~mm}$ \\
\hline$-4.2^{\circ} \mathrm{C}$ & $10^{\circ} \mathrm{C}$ & $0.4^{\circ} \mathrm{C}$ & $-9.2^{\circ} \mathrm{C}$ & $-0.8^{\circ} \mathrm{C}$ & $750 \mathrm{~mm}$ \\
\hline
\end{tabular}

In theory, it is possible that the Tymphian glaciers formed prior to the rock glaciers during an interval when precipitation was sufficiently high. The rock glaciers may then have formed as climate became drier towards the global last glacial maximum ( $c f$. Hughes et al., 2003). If the rock glaciers formed during glacier retreat, it is likely that this was associated with drier conditions and not increased temperatures. Since the relict rock glaciers are found outside of, and lower than, the Tymphian glacial deposits, their lower boundary represents the lowest limit of discontinuous permafrost and the $-2{ }^{\circ} \mathrm{C}$ isotherm during the last cold stage. Thus, even if the rock glaciers do post-date the glaciers, it is very unlikely that conditions were colder than during the maximum extent of the cirque glaciers.

Other potential limitations in the palaeotemperature and palaeoprecipitation reconstructions and the comparison with modern climate include: a) altitudinal temperature gradients may be different to the $0.6^{\circ} \mathrm{C}$ per $100 \mathrm{~m}$ altitude used here, since a wide range of gradients $\left(0.5-0.8^{\circ} \mathrm{C}\right.$ per $\left.100 \mathrm{~m}\right)$ are possible under different conditions (Whiteman, 2000); and, b) the mean annual temperature distribution may not have been sinusoidal. The lapse rate problem, however, cannot be easily resolved. Temperature and associated precipitation reconstructions should therefore be considered as approximations, even where seemingly precise values are given. The second major assumption, of a sinusoidal mean monthly temperature distribution, is supported by sinusoidal distributions for most climatic stations around the world, from both maritime and continental localities. Moreover, modern mean monthly temperature distributions at Ioannina closely match a sinusoidal distribution ( $c f$. World Meteorological Organisation, 1998).

A further potential problem is the fact that the Pindus Mountains are tectonically active, with uplift in the
Epirus region estimated at between $c$. $40-80 \mathrm{~m}$ per 100,000 years (King and Bailey 1985). In addition, global sea-level is estimated to have lowered by 130 $135 \mathrm{~m}$, relative to current sea level, during the global last glacial maximum (Yokoyama et al., 2000). However, tectonic uplift and changes in relative sea level do not affect any extrapolation of temperature to different altitudes, assuming that uplift between extrapolated points has been relatively uniform. Only when extrapolations are to modern sea level, will comparisons with modern-day values be problematic and this has not been attempted here.

\section{Regional and local climatic controls on glacier and rock glacier formation}

The Tymphian represents the last glacial stage in Greece and is comparable with the Würmian and Weichselian Stages of the Alps and northern Europe. The relatively small size of the Tymphian glaciers in the northern Pindus Mountains was comparable to the situation on Mount Olympus, in northeastern Greece, where glaciers were restricted to valley heads at this time (Smith et al., 1997). ELAs were also similar (Olympus: 2200m a.s.l., northern Pindus: 2174-2241 m a.s.l.) although, given that the climate of northeastern Greece is currently much more continental (Furlan, 1977), it is likely that climate was colder and drier on Mount Olympus.

Aspect appears to have had little influence on glacier ELAs on Mount Tymphi and few patterns of local variability are apparent-not even between north- and south-facing glaciers. However, the lowermost glacier, the Megalon Litharion glacier (ELA: $2100 \mathrm{~m}$ a.s.l.), was a southeast-facing glacier and would have been shaded from afternoon sunshine by the Krevati cliffs, a ridge on its western side (Fig. 3). However, all but one of the rock 
glaciers on Tymphi formed in the northern cirques and reflect the greater importance of local shading on frostshattered debris supply.

On Mount Smolikas, glaciers had a mean ELA of $2241 \mathrm{~m}$ a.s.1., $67 \mathrm{~m}$ higher than the mean ELA on Mount Tymphi. Moreover, the highest glaciers of Mount Smolikas (Cirque 2 and Cirque 3/4 glaciers), were $125 \mathrm{~m}$ higher than the highest glacier on Tymphi. The main reason for this was probably the lower precipitation during the maximum extent of the Tymphian glaciation on Mount Smolikas, compared to Mount Tymphi. Temperatures at a given altitude are unlikely to have been significantly different. Accordingly, the $67 \mathrm{~m}$ difference in mean ELAs corresponds to a mean annual precipitation c. $160 \mathrm{~mm}$ lower at the mean ELA of the Mount Smolikas glaciers, compared with Mount Tymphi, calculated using the Ohmura et al. (1992) equation and assuming a lapse rate of $0.6{ }^{\circ} \mathrm{C}$ per $100 \mathrm{~m}$. A similar situation appears to be the case today, since mean annual precipitation at Pades (1170 m a.s.1.) at the foot of Mount Smolikas is $1247 \mathrm{~mm}$, whilst at Skamnelli (1180 m a.s.1.) on Mount Tymphi, on a similar south-facing slope, mean annual precipitation is $1721 \mathrm{~mm}$ (Fotiadi et al., 1999). This difference can probably be attributed to the more northeasterly, inland position of Mount Smolikas.

All the Mount Smolikas glaciers formed in north- or northeast-facing cirques (Fig. 4) and, unlike on Mount Tymphi, aspect appears to have been an important control on glacier formation. This is likely to have been the result of lithological and structural geological differences between the two mountains. On Mount Tymphi, karstic hollows (dolines) on the southern slopes would have favoured snow accumulation compared with the steeper faulted northern escarpment (Fig. 3). The ophiolite of Mount Smolikas is more massive and structurally less complex. This, and the fact that ophiolite bedrock weathers into smooth forms, unlike the Tymphi limestones, would not have afforded local topographical complexity and snow accumulation would have been strongly controlled by aspect. Furthermore, the light colour of the limestone on Mount Tymphi is likely to have enhanced the albedo of debris cover on south-facing glaciers compared with the very dark, ophiolite lithology on Mount Smolikas.

The absence of rock glaciers on Mount Smolikas, in contrast to their widespread formation on Mount Tymphi, can be attributed to lithological controls on debris supply since the limestones of the latter area readily fracture along joints and bedding planes unlike the massive ophiolites of Mount Smolikas. However, a rock glacier did form after the retreat of the Tymphian glacier maximum and formed together with small cirque glaciers during the Late-glacial. A similar readvance is not recorded on Mount Tymphi because the glacial and permafrost threshold occurred above the highest cirque floors (Hughes et al., in press-a).

The climate during the glacier maximum of the Tymphian at $2174 \mathrm{~m}$ a.s.1. (the ELA of the Mount Tymphi glaciers) was characterised by mean annual precipitation of c. $2300 \pm 200 \mathrm{~mm}$ at $2174 \mathrm{~m}$ a.s.l., an annual mean monthly temperature range $c .20^{\circ} \mathrm{C}$ and a mean annual temperature of $-4.2{ }^{\circ} \mathrm{C}$. The mean temperature of the coldest month is calculated at less than $-14{ }^{\circ} \mathrm{C}$ whilst the mean temperature of the warmest month was just under $6{ }^{\circ} \mathrm{C}$ (Table 3). The combination of a mean summer temperature (June/July/August) of $4.9^{\circ} \mathrm{C}$ (Tables 2 and 3) and a mean annual precipitation of $2300 \pm 200 \mathrm{~mm}$ at the glacier ELA is comparable to modern conditions at Nigardsbreen, Norway $\left(61^{\circ} 43^{\prime} \mathrm{N}\right.$, $7^{\circ} 08^{\prime} \mathrm{E}$, ELA: $1545 \mathrm{~m}$ a.s.l.). Here, the mean winter mass balance plus summer precipitation (effectively annual precipitation) for the interval 1964-1980 was $2300 \mathrm{~mm}$ and the mean summer temperature (June/July/ August) was $4.9^{\circ} \mathrm{C}$ (Ohmura et al., 1992). It can be argued, therefore, that the mass balance regime of the Tymphian glaciers in the northern Pindus Mountains would have resembled those of present-day maritime subarctic glaciers.

In lower areas, such as at Ioannina (483 $\mathrm{m}$ a.s.1.), the mean temperature of the coldest month is likely to have been less than $-4{ }^{\circ} \mathrm{C}$, whilst during the warmest month temperatures are likely to have averaged nearly $16{ }^{\circ} \mathrm{C}$. Interestingly, the mean January temperature of $c .-4{ }^{\circ} \mathrm{C}$ is close to the value of $-5^{\circ} \mathrm{C}$ derived for the coldest part

Table 3

Mean monthly temperature (MMT) and mean annual temperature (MAT) reconstructions for the glacier maximum of the Tymphian at the ELA of the former glaciers and at Ioannina. The Ioannina temperature data is extrapolated from the glacier temperatures using a lapse rate of $0.6^{\circ} \mathrm{C}$ per $100 \mathrm{~m}$ elevation

\begin{tabular}{|c|c|c|c|c|c|c|c|c|c|c|c|c|c|}
\hline & Jan & Feb & Mar & Apr & May & Jun & Jul & Aug & Sep & Oct & Nov & Dec & $\operatorname{MAT}\left({ }^{\circ} \mathrm{C}\right)$ \\
\hline $\begin{array}{l}\text { Tymphian Stage MMT }\left({ }^{\circ} \mathrm{C}\right) \\
\text { Glacier ELA ( } 2174 \text { m a.s.l. })\end{array}$ & -14.2 & -12.9 & -9.2 & -4.2 & 0.8 & 4.4 & 5.8 & 4.4 & 0.8 & -4.2 & -9.2 & -12.9 & -4.2 \\
\hline $\begin{array}{l}\text { Tymphian Stage MMT }\left({ }^{\circ} \mathrm{C}\right) \\
\text { Ioannina ( } 483 \mathrm{~m} \text { a.s.l.) }\end{array}$ & -4.1 & -2.8 & 0.9 & 5.9 & 10.9 & 14.6 & 15.9 & 14.6 & 10.9 & 5.9 & 0.9 & -2.8 & 5.9 \\
\hline
\end{tabular}


Table 4

Mean monthly temperature and monthly precipitation data for Ioannina (39.7 N 20.8 E, $484 \mathrm{~m}$ a.s.1.) over the period 1961-1990 (World Meteorological Organisation 1998)

\begin{tabular}{|c|c|c|c|c|c|c|c|c|c|c|c|c|c|}
\hline & Jan & Feb & Mar & Apr & May & Jun & Jul & Aug & Sep & Oct & Nov & Dec & \\
\hline Mean Temp $\left({ }^{\circ} \mathrm{C}\right)$ & 4.6 & 6.1 & 8.9 & 12.6 & 17.4 & 21.7 & 24.8 & 24.2 & 20.3 & 14.9 & 9.7 & 5.8 & MAT: 14.3 \\
\hline Precipitation $(\mathrm{mm})$ & 130.3 & 115.5 & 98.2 & 76.0 & 66.9 & 46.8 & 28.5 & 28.4 & 54.9 & 95.5 & 164.5 & 172.3 & Pann: 1077.8 \\
\hline
\end{tabular}

of the last cold stage based on the results of a palaeoclimate simulation using a limited area model (Pollard and Barron, 2003; Tzedakis et al., 2003, 2004). Precipitation estimates for sites such as Ioannina are difficult to extrapolate from the highest mountains given uncertainties regarding altitudinal precipitation gradients. During the most severe phase of the last cold stage, Tzedakis et al. $(2003,2004)$ estimated that mean annual precipitation was $655 \mathrm{~mm}$ at Ioannina, representing a reduction of $545 \mathrm{~mm}(45 \%)$ from a modern annual precipitation of $1200 \mathrm{~mm}$ based on the 1951-1981 record ( $c f$. National Statistical Service of Greece, 1981). However, it is likely that precipitation gradients were more pronounced than today, since cold air has less moisture capacity than warmer air. Today, the mean annual precipitation at Ioannina $(1078 \mathrm{~mm}$ based on the 1961-1990 record; Table 4) is at least half that which falls in the mountains $(>2000 \mathrm{~mm})$ and it is probable that this ratio was increased under a glacial climate.

The geomorphological relationship between the glacier and the rock glacier deposits strongly suggests a diachronous sedimentary assemblage whereby upon a shift to drier conditions, snow accumulation was exceeded by debris accumulation. This caused the glaciers to retreat and become buried by debris, forming rock glaciers. In some instances, such as in the Tsouka Rossa cirque, it is clear that rock glaciers formed outside former cirque glacier limits and can be described as debris rock glaciers. Others formed in the highest parts of cirques and can be described as talus rock glaciers (Hughes et al., 2003). The debris rock glacier appears to have formed contemporaneously with the cirque glaciers. However, this rock glacier, as well as talus rock glaciers in neighbouring cirques could have continued to form after glacier retreat, provided temperatures were cold enough. In fact, the talus rock glaciers may well have buried and incorporated moraines formed by earlier cirque glaciers during the Tymphian Stage.

\section{Identifying potential climates for glacier formation in nearby pollen records}

It is possible to identify potential climatic conditions for glacier formation based on the high resolution pollen record from Ioannina (Tzedakis et al., 2002, 2004). The pollen record at Ioannina for the last cold stage is characterised by major variations in arboreal pollen frequencies over millennial time scales, which closely match variations in Mediterranean sea surface temperatures (cf. Cacho et al., 1999) as well as isotope records in North Atlantic marine sediments (cf. Shackleton et al., 2000) and the Greenland ice sheet ( $c f$. Grootes and Stuiver, 1997). The link between these records is closely related to moisture supply, since polar water incursions into the Mediterranean Sea during Heinrich events would have inhibited evaporation in the Mediterranean Basin, reduced precipitation on land and resulted in moisture stress in vegetation communities. Given the importance of precipitation in controlling glacier mass balance (Ohmura et al., 1992), it would be expected that Mediterranean mountain glaciers would have formed and decayed in response to these millennial-scale climate changes.

Comparisons can be made between the record of mountain glaciers in the Pindus Mountains and nearby pollen record at Ioannina to identify intervals climatically favourable for glacier formation. Three possible types can be identified:

Type $A$ major stadials characterised by low arboreal pollen, both including and excluding Pinus and Juniperus;

Type $B$ intermediate phases between the most pronounced peaks and troughs of major stadials and interstadials; and,

Type $C$ intervals characterised by large differences between total arboreal pollen frequencies and arboreal pollen frequencies, excluding Pinus and Juniperus. These are identified in Fig. 5 and discussed in turn below.

Glacier build-up may have been favoured by cold episodes during major stadials identified in the pollen record, which appear to correlate with some Heinrich events. At Kopais, in central Greece (Fig. 1), arboreal pollen abundances appear to collapse at times correlating with Heinrich Events and show an 'intermediate' decline during intervening stadials (Tzedakis et al., 2004). However, at Ioannina, in the Pindus Mountains, 


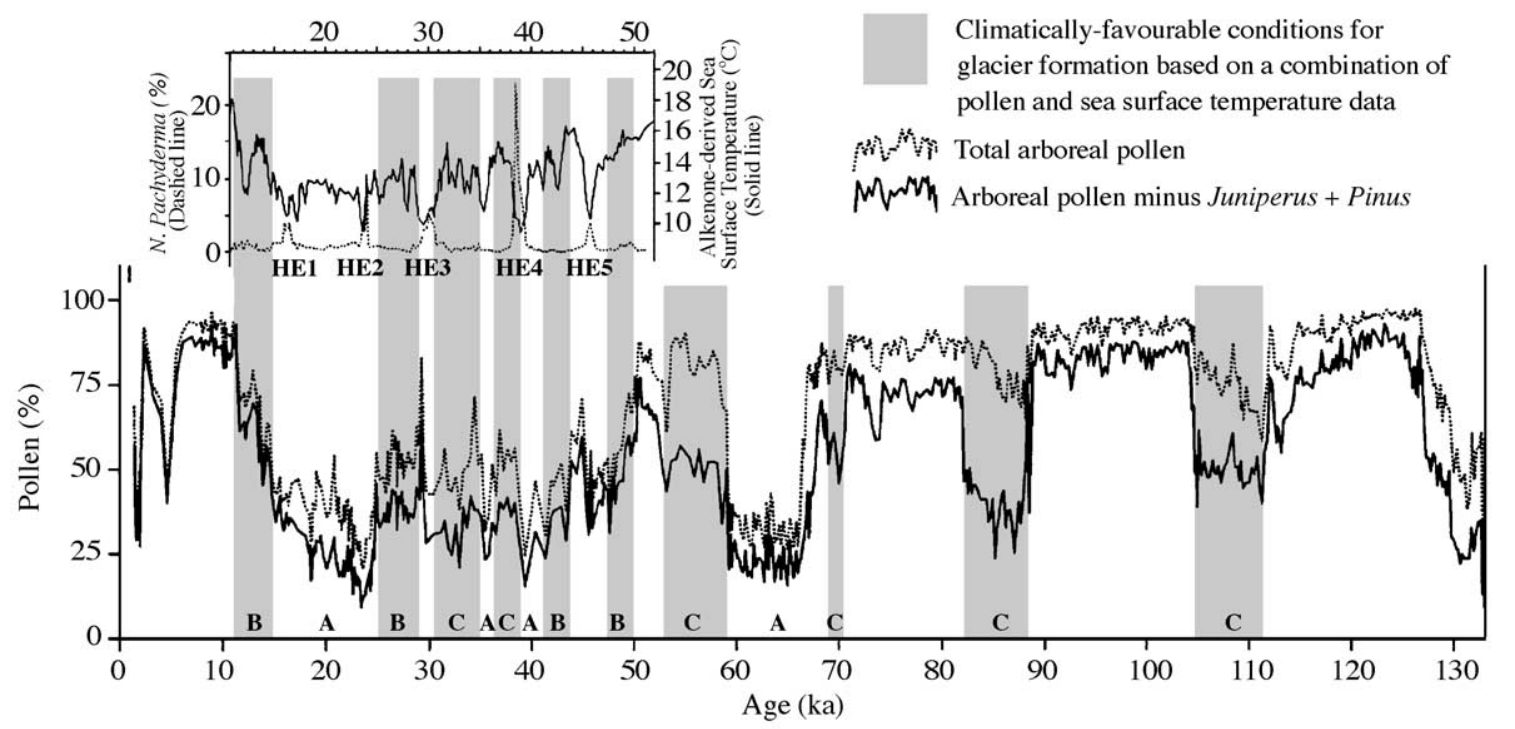

Fig. 5. Summary pollen percentage curves from the Ioannina I284 sequence in northwest Greece, spanning the last glacial cycle. Potential intervals suitable for glacier formation are indicated by letters $A$ : major stadials characterised by low arboreal pollen, both including and excluding Pinus and Juniperus; $B$ : intermediate phases between the apices of major stadials and interstadials; and, $C$ : intervals characterised by large differences between total arboreal pollen frequencies and arboreal pollen frequencies, excluding Pinus and Juniperus. All other intervals represent major interstadials or interglacials. Both B and C types - the more favourable conditions for glaciation - are highlighted by shading. The upper graph depicts variations in the percentage of Neogloboquadrina pachyderma (sinstral) and alkenone-derived sea-surface temperatures in marine core MD95-2043 from the Alboran Sea, in the western Mediterranean (adapted from Cacho et al., 1999 and Tzedakis et al., 2004).

even the most extreme events were not sufficiently severe to completely eliminate tree populations (Fig. 5) and not all Heinrich events are clearly represented. Nevertheless, Heinrich events (HE) 2 and 4 are clearly marked by a significant reduction in tree populations and this is considered to represent partly a response to moisture stress (Tzedakis et al., 2004). In contrast, HE1 and HE3 are poorly represented in the pollen record at Ioannina and, thus, moisture availability is likely to have been greater in the Pindus Mountains at these times than during HE2 and HE4. The most severe phases of moisture stress at Ioannina, corresponding with HE 2 and HE 4 are shown as Type $A$ in Fig. 5. Reduced precipitation during these stadials would have inhibited glacier build-up and would have forced the retreat of pre-existing glaciers. The cold and dry climates would have instead favoured the formation of periglacial phenomena such as rock glaciers.

During Dansgaard-Oeschger interstadials, the mean temperature of the coldest month and annual precipitation appears to have been similar to those at the present day, based on pollen evidence in the Alboran Sea in the western Mediterranean Basin (Sánchez Goñi et al., 2002). However, warm temperatures during interstadials would have counteracted the effects of increased moisture supply on glacier mass balance. Given that the modern snowline in the Pindus Mountains is estimated to occur at over $3000 \mathrm{~m}$ a.s.l. (Messerli, 1980), it is unlikely that glaciers could have formed under conditions similar to today. Even if summer temperatures were lower than present, they would have to fall by $c .5{ }^{\circ} \mathrm{C}$ in order to depress the snow line from $3000 \mathrm{~m}$ to $2174 \mathrm{~m}$ a.s.1. - the ELA of the Tymphian glaciers (based on lapse rate of $0.6{ }^{\circ} \mathrm{C} / 100$ altitude). Glaciers in the Pindus Mountains are, therefore, likely to have decayed at the most pronounced apices of stadials and interstadials and advanced during more intermediate phases. Examples of such intermediate phases have been identified from the pollen record at Ioannina and are identified as Type $B$ in Fig. 5. However, defining precise glacier-climate conditions from the vegetation record is difficult. The last occurrence of such intermediate conditions before the most severe and driest phase of the Tymphian at 24,000 cal. years BP, was during the interval between c. 25,000 and 30,000 cal. years BP (Fig. $5)$. The end of this interval corresponds with the age of a cement, dated using U-series, within a major alluvial unit rich in glacially derived fines in the Voidomatis basin, downstream of the largest Late Pleistocene glaciers on Mount Tymphi (Hamlin et al., 2000).

Conditions suitable for glacier formation in the Pindus Mountains may also correspond to intervals of high total arboreal pollen frequencies yet low arboreal pollen frequencies minus Juniperus and Pinus. During 
these phases, sustained high percentages of total arboreal pollen (including Juniperus and Pinus) yet much lower arboreal pollen minus Juniperus and Pinus, may reflect moist yet cold conditions. Juniperus and Pinus species are tolerant of cold conditions and today characterise part of the high-mountain vegetation assemblage in many Mediterranean mountain areas (Reille et al., 1997; García et al., 1999; Trakolis et al., 2000). Examples of these phases are indicated in Fig. 5 as Type $C$. Thus, in addition to the intermediate (Type B) phases, such as between 25,000 and 30,000 cal. years $\mathrm{BP}$ described above, there are at least ten intervals (Types B and C) where glacier formation can be envisaged during the Tymphian. What is certain, given the dramatic oscillations of climate in the Mediterranean during the last cold stage (Allen et al., 1999; Tzedakis et al., 2004; Chrondrogianni et al., 2004), is that glacier behaviour would have been unstable. In fact, given the relatively small size of the former glaciers, they are also likely to have been highly responsive to decadal- and centennial-scale change. However, in the absence of further evidence, establishing the precise timing of glacier advance and retreat from the discontinuous glacial sedimentary record will remain elusive.

Although it is difficult to provide conclusive evidence for the precise timing of phases of glacier advance and retreat based on the glacial stratigraphical record, the timing of the last local glacier maximum can be constrained by comparing the glacier-climate reconstructions with those produced from other records. For example, it is unlikely, based on the palaeoclimatic reconstructions outlined above, that the Greek glaciers would have reached their maximum during the most severe phase of cold and dry climate during the Tymphian, indicated in the pollen record at c. 24,000 cal. years BP (Tzedakis et al., 2002, 2004). Neither is it likely that the glacier maximum in the Pindus corresponds with the global last glacial maximum at c. 21,000 cal. years BP (cf. Clark and Mix, 2002) (Fig. 5).

A local or regional glacier maximum preceding that in those areas covered by large ice sheets, such as in the Alps and northern Europe, is supported by geochronological evidence obtained from other locally glaciated mountain areas in the Mediterranean ( $c f$. Hughes et al., in press-b). In the Italian Appenines, for example, maximum glacier extension during the Würmian occurred between $31,500 \pm 630{ }^{14} \mathrm{C}$ years BP $(34770$ \pm 638 cal. years BP) and $22,680 \pm 630{ }^{14} \mathrm{C}$ years BP $(26,239 \pm 789 \mathrm{cal}$. years BP) (Girauldi and Frezzotti, 1997). In common with the record in Greece, this glacial maximum appears to pre-date the most severe phase of climate represented in the pollen record, since at Lago di Monticchio, a long lacustrine sequence in central Italy, the lowest arboreal pollen abundances occurred between 25,900 and 14,300 cal. years BP (22,350$12,500{ }^{14} \mathrm{C}$ years BP) (Allen et al., 2000). Early glacier maxima have also been documented in other locally glaciated mountain areas of Europe, such as in the Pyrenees (García-Ruiz et al., 2003; Jalut et al., 1992) and the Vosges mountains to the north of the Alps (Seret et al., 1990). In addition, even larger ice sheets further north, such as the British ice sheet, are now thought to have reached a maximum extent prior to the global last glacial maximum (Bowen et al., 2002). There is, therefore, consistent evidence from the glacial records in locally glaciated mountains in Europe, and even from areas that contained larger ice sheets, for a glacier maximum that preceded the global glacial maximum at c. 21,000 cal. years BP.

As noted earlier, a strong candidate for the last local glacier maximum in the Pindus Mountains is the interval between 30,000 and 25,000 cal. years BP, which corresponds with a major phase of fluvial aggradation in the Voidomatis River, downstream of the largest glaciers. However, potential conditions for significant glacier formation can be recognised for at least nine other intervals within the Tymphian Stage: the earliest being between $c$. 111,000 and 105,000, corresponding to Stadial 1 in the Ioannina pollen record and MIS $5 \mathrm{~d}$ ( $c f$. Tzedakis et al., 2002); and the last between $c .15,000-$ 10,000 years BP, during the Late-glacial ( $c f$. Lawson et al., 2004). It is during the latter interval that the last glaciers formed in Greece, in the highest cirques of Mount Smolikas - the highest peak of the Pindus Mountains (Hughes et al., in press-a).

\section{Conclusions}

Glaciers in the Pindus Mountains of northern Greece formed during the last cold stage (Tymphian) under a cold and moist climate. The local glacier maximum was characterised by a mean summer (June/July/August) temperature of $4.9^{\circ} \mathrm{C}$ and mean annual precipitation of $2300 \pm 200 \mathrm{~mm}$ at the ELA (2174 $\mathrm{m}$ a.s.1.). This glacierclimate relationship closely resembles that which occurs today at the ELA of maritime Scandinavian glaciers. However, strong altitudinal precipitation gradients would have intensified the contrast between upland and lowland climates resulting in a marked contrast between dry lowland and moist upland environments.

Glacier behaviour during the Tymphian would have been closely controlled by changes in precipitation 
and temperature. Increasingly dry conditions in the Mediterranean region towards the global last glacial maximum resulted in glacier retreat, a dominance of debris supply over snow accumulation, and widespread rock glacier formation in the cirques of Mount Tymphi. It is proposed that glacier formation would not have occurred during some major stadials and interstadials. During major stadials, cooler sea surface temperatures in the Mediterranean would have inhibited atmospheric moisture supply resulting in negative glacier mass balances and consequent retreat on land. Conversely, during major interstadials, warmer air temperatures would have promoted ablation forcing glacier retreat, offsetting increased precipitation caused by warmer sea surface temperatures. The most favourable conditions for glaciation in the Mediterranean mountains are more likely to have been reached during more intermediate conditions, when moisture supply was sufficient yet summer temperatures were not too warm. Several such intervals can be recognised in the high resolution vegetation record from Ioannina northwest Greece. Whilst the static glacier-climate model presented in this paper provides some important insights into glacier maximum conditions, a temporally dynamic glacier-climate model is required to understand glacier behaviour in response to millennial-scale climate change. This is the case in the Mediterranean mountains and in all locally glaciated mountain areas.

\section{Acknowledgements}

PDH was supported by a University of Cambridge Domestic Research Studentship (2001-2004) and a University of Manchester Faculty of Humanities Fellowship (2004-2006). Fieldwork was supported by grants from the following: Darwin College, University of Cambridge; Cambridge European Trust; Quaternary Research Association; British Geomorphological Research Group; Worts Travelling Scholarship - University of Cambridge; Cambridge Philosphical Society; and, the Department of Geography, University of Cambridge. The U-series support was provided by a Natural Environment Research Council Grant (Reference Number: IP/754/0302) and samples were processed at the Open University Uranium Series Facility. All field work was undertaken with permission and support of the Institute of Geological and Mineral Exploration (IGME) of Greece. We would like to thank Roger Braithwaite (The University of Manchester) for insightful discussion, particularly regarding issues relating to glacier mass balance and climate.

\section{References}

Ahlmann, H.W., 1948. Glaciological Research on the North Atlantic Coasts. Royal Geographical Society, London. Research Series 1

Allen, J.R.M., Brandt, U., Brauer, A., Hubberten, H.W., Huntly, B., Keller, J., Kraml, M., Mackensen, A., Mingram, J., Negendank, J. F.W., Nowaczyk, N.R., Oberhansli, H., Watts, W.A., Wulf, S., Zolitschka, B., 1999. Rapid environmental changes in southern Europe during the last glacial period. Nature 400, 740-743.

Allen, J.R.M., Watts, W.A., Huntley, B., 2000. Weichselian palynostratigraphy, palaeovegetation and palaeoenvironment; the record from Lago Grande di Monticchio, southern Italy. Quaternary International 73/74, 91-110.

Ballantyne, C.K., 1989. The Loch Lomond Readvance on the Isle of Skye, Scotland: glacier reconstruction and palaeoclimatic implications. Journal of Quaternary Science 4, 95-108.

Bar-Matthews, M., Ayalon, A., Kaufman, A., Wasserburg, G.J., 1999. The Eastern Mediterranean palaeoclimate as a reflection of regional events: Soreq Cave, Israel. Earth and Planetary Science Letters 166, 85-95.

Barsch, D., 1978. Rock glaciers as indicators for discontinuous alpine permafrost: an example from the Swiss Alps. Proceedings of the Third International Conference on Permafrost, vol. 1. National Research Council of Canada, Ottawa, pp. 349-352.

Barsch, D., 1996. Rock Glaciers: Indicators for the Present and Former Geoecology in High Mountain Environments. Springer Verlag, Berlin. 331 pp.

Bartov, Y., Goldstein, S.L., Stein, M., Enzel, Y., 2003. Catastrophic arid episodes in the Eastern Mediterranean linked with the North Atlantic Heinrich Events. Geology 31, 439-442.

Belloni, S., Pelfini, M., Smiraglia, C., 1988. Morphological features of the active rock glaciers in the Italian Alps and climatic correlations. Permafrost, Fifth International Conference, Proceedings, Trondheim, vol. 1, pp. 678-682.

Bowen, D.Q., Phillips, F.M., McCabe, A.M., Knutz, P.C., Sykes, G.A. 2002. New data for the Last Glacial Maximum in Great Britain and Ireland. Quaternary Science Reviews 21, 89-101.

Brazier, V., Kirkbride, M.P., Owens, I.F., 1998. The relationship between climate and rock glacier distribution in the Ben Ohau Range, New Zealand. Geografiska Annaler 80A, 193-207.

Cacho, I., Grimalt, J.O., Pelejero, C., Canals, M., Sierro, F.J., Flores, J. A., Shackleton, N.J., 1999. Dansgaard-Oeschger and Heinrich event imprints in Alboran Sea palaeotemperatures. Paleoceanography 14, 698-705.

Carton, A., Dramis, F., Smiraglia, C., 1988. A first approach to the systematic study of rock glaciers in the Italian Alps. Permafrost, Fifth Annual International Conference, Proceedings, vol. 1, pp. 712-717.

Chondrogianni, C., Ariztegui, D., Rolph, T., Juggins, S., Shemesh, A., Rietti-Shati, M., Niessen, F., Guilizzoni, P., Lami, A., McKenzie, J. A., Oldfield, F., 2004. Millennial to interaanual climate variability in the Mediterranean during the Last Glacial Maximum. Quaternary International 122, 31-41.

Clark, P.U., Mix, A.C., 2002. Ice sheets and sea level of the Last Glacial Maximum. Quaternary Science Reviews 21, 1-7.

Dansgaard, W., Johnsen, S.J., Cdlausem, H.B., Dahl-Jensen, D., Gundestrup, N.S., Hammer, C.U., Hvidberg, C.S., Steffensen, J.P., Sveinbjörnsdottir, A.E., Jouzel, J., Bond, G., 1993. Evidence for general instability of past climate from a 250 -year ice-core record. Nature 364, 218-220. 
Fisch Sr., W., Fisch Jr., W., Haeberli, W., 1977. Electrical DC resistivity soundings with long profiles on rock glaciers and moraines in the Alps of Switzerland. Zeitschrift für Gletscherkunde und Glazialgeologie 13, 239-260.

Fotiadi, A.K., Metaxas, D.A., Bartzokas, A., 1999. A statistical study of precipitation in northwest Greece. International Journal of Climatology 19, 1221-1232.

Furlan, D., 1977. The climate of southeast Europe. In: Wallen, C.C. (Ed.), Climates of Central and Southern Europe. Elsevier, Amsterdam, pp. 185-223.

García, D., Zamora, R., Hódar, J.A., Gómez, J.M., 1999. Age structure of Juniperus communis L. in the Iberian peninsula: conservation of remnant populations in Mediterranean mountains. Biological Conservation 87, 215-220.

García-Ruiz, J.M., Valero-Garcés, B.L., Martí-Bono, C., GonzálezSampériz, P., 2003. Asynchroneity of maximum glacier advances in the central Spanish Pyrenees. Journal of Quaternary Science 18, $61-72$.

Geraga, M., Tsaila-Monopolis, S., Ioakim, C., Papatheodorou, G., Ferentinos, G., 2005. Short-term changes in the southern Aegean Sea over the last 48,000 years. Palaeoceanoraphy, Palaeoclimatology, Palaeoecology 220, 311-332.

Girauldi, C., Frezzotti, M., 1997. Late Pleistocene glacial events in the Central Appenines, Italy. Quaternary Research 48, 280-290.

Grootes, P.M., Stuiver, M., 1997. Oxygen 18/16 variability in Greenland snow and ice with $10^{3}$ - to $10^{5}$-year time resolution. Journal of Geophysical Research 102 (26), 455-26470.

Haeberli, W., 1982. Klimarekonstruktionen mit Gletscher-PermafrostBeziehungen. Baseler Beiträge zur Physiogeographie 4, 9-17.

Haeberli, W., 1985. Creep of mountain permafrost: internal structure and flow of alpine rock glaciers. Mitteilungen der Versuchsanstalt für Wasserbau, Hydrologie und Glaziologie, vol. 77. Zürich.

Hamlin, R.H.B., Woodward, J.C., Black, S., Macklin, M.G., 2000. Sediment fingerprinting as a tool for interpreting long-term river activity: the Voidomatis basin, Northwest Greece. In: Foster, I.D.L. (Ed.), Tracers in Geomorphology. Wiley, Chichester, pp. 473-501.

Hughes, P.D., 2004. Quaternary Glaciation in the Pindus Mountains, Northwest Greece. Ph.D. thesis, University of Cambridge. 341 pp.

Hughes, P.D., Gibbard, P.L., Woodward, J.C., 2003. Relict rock glaciers as indicators of Mediterranean palaeoclimate during the Last Glacial Maximum (Late Würmian) of northwest Greece. Journal of Quaternary Science 18, 431-440.

Hughes, P.D., Gibbard, P.L., Woodward, J.C., 2005. A formal stratigraphical approach for Quaternary glacial records in mountain regions. Episodes 28, 85-92.

Hughes, P.D., Woodward, J.C., Gibbard, P.L., in press-a. The last glaciers of Greece. Zeitschrift für Geomorphologie 50.

Hughes, P.D., Woodward, J.C., Gibbard, P.L. in press-b. The glacial history of the Mediterranean mountains. Progress in Physical Geography 30.

Humlum, O., 1998. Rock glaciers on the Faeroe Islands, the North Atlantic. Journal of Quaternary Science 13, 293-307.

IGME 1970. 1:50,000 Geological map of Greece. Tsepelovon Sheet. Athens: Institute of Geological and Mineral Exploration.

IGME 1987. 1:50,000 Geological map of Greece. Konitsa Sheet. Institute of Geological and Mineral Exploration: Athens.

Imbrie, J., Hays, J.D., Martinson, D.G., McIntyre, A., Mix, A.C., Morley, J.J., Pisias, N.G., Prell, W.L., Shackleton, N.J., 1984. The orbital theory of Pleistocene climate: support from a revised chronology of the marine ${ }^{18} \mathrm{O}$ record. In: Berger, A., Imbrie, J., Hays, G., Kukla, G., Saltzman, B. (Eds.), Milankovitch and Climate. Reidel, Dortrecht, pp. 269-306.
Jalut, G., Montserrat, J., Fontunge, M., Delibrias, G., Vilaplana, J., Juliá, R., 1992. Glacial to interglacial vegetation changes in the northern and southern Pyrenees: deglaciation, vegetation cover and chronology. Quaternary Science Reviews 11, 449-480.

King, G., Bailey, G., 1985. The palaeoenvironment of some archaeological sites in Greece: the influence of accumulated uplift in a seismically active region. Proceedings of the Prehistoric Society $51,273-282$.

Lawson, I.T., Frogley, M., Bryant, C., Preece, R., Tzedakis, P.C., 2004. The Late glacial and Holocene environmental history of the Ioannina basin, north-west Greece. Quaternary Science Reviews $23,1599-1625$.

Loewe, F., 1971. Considerations of the origin of the Quaternary icesheet in North America. Arctic and Alpine Research 3, 331-344.

Martinson, D.G., Pisias, N.G., Hays, J.D., Imbrie, J., Moore, T.C., Shackleton, N.J., 1987. Age dating and the orbital theory of the ice ages: development of a high resolution $0-300,000$ year chronostratigraphy. Quaternary Research 27, 1-29.

Messerli, B., 1980. Mountain glaciers in the Mediterranean area and in Africa. World Glacier Inventory. World Glacier Inventory, 126. International Association of Hydrological Sciences, pp. 197-211.

National Statistical Service of Greece, 1981. Statistical Yearbook of Greece: Athens.

Nesje, A., Dahl, S.O., 2000. Glaciers and Environmental Change: Key Issues in Environmental Change Series. Arnold.

Ohmura, A., Kasser, P., Funk, M., 1992. Climate at the equilibrium line of glaciers. Journal of Glaciology 38, 397-411.

Pollard, D., Barron, E.J., 2003. Causes of model-data discrepancies in European climate during Oxygen Isotope Stage 3 with insights from the Last Glacial Maximum. Quaternary Research 59, 108-113.

Peyron, O., Guiot, J., Cheddadi, R., Tarasov, P., Reille, M., de Beaulieu, J.-L., Bottema, S., Andrieu, V., 1998. Climatic reconstruction in Europe for 18,000 YR B.P. from pollen data. Quaternary Research 49, 183-196.

Porter, S.C., 1975. Equilibrium-line altitudes of late Quaternary glaciers in the Southern Alps, New Zealand. Quaternary Research $5,27-47$.

Reille, M., Gamisans, J., de Beaulieu, J.-L., Andrieu, V., 1997. The Late-glacial at Lacde Creno (Corsica, France): a key new site in the western Mediterranean basin. New Phytologist 135, 547-559.

Sánchez Goñi, M.F., Cacho, I., Turon, J.-L., Guiot, J., Sierro, F.J., Peypouquet, J.O., Grimalt, J.O., Shackleton, N.J., 2002. Synchroneity between marine and terrestrial responses to millennial scale climatic variability during the last glacial period in the Mediterranean region. Climate Dynamics 19, 95-105.

Seret, G., Dricot, J., Wansard, G., 1990. Evidence for an early glacial maximum in the French Vosges during the last glacial cycle. Nature 346, 453-456.

Shackleton, N.J., Hall, M.A., Vincent, E., 2000. Phase relationships between millennial-scale events 64,000 to 24,000 years ago. Paleoceanography 15, 565-569.

Sissons, J.B., 1974. A Late glacial ice-cap in the central Grampians, Scotland. Transactions of the Institute of British Geographers 62, 95-114.

Smith, G.W., Nance, R.D., Genes, A.N., 1997. Quaternary glacial history of Mount Olympus. Geological Society of America Bulletin 109, 809-824.

Trakolis, D., Platis, P., Meliadis, I., 2000. Biodiversity and conservation actions on Mount Voras, Greece. Environmental Management 26, 145-151.

Tzedakis, P.C., 1993. Long-term tree populations in northwest Greece through multiple Quaternary climatic cycles. Nature 364, 437-440. 
Tzedakis, P.C., 1994. Vegetation change through glacial-interglacial cycles: a long pollen sequence perspective. Philosophical Transactions of the Royal Society of London B345, 403-432.

Tzedakis, P.C., 1999. The last climatic cycle at Kopais, central Greece. Journal of the Geological Society 156, 425-434.

Tzedakis, P.C., Lawson, I.T., Frogley, M.R., Hewitt, G.M., Preece, R. C., 2002. Buffered tree population changes in a Quaternary refugium: evolutionary implications. Science 297, 2044-2047.

Tzedakis, P.C., McManus, J.F., Hooghiemstra, H., Oppo, D.W., Wijmstra, T.A., 2003. Comparsion of changes in vegetation in northeast Greece with records of climate variability on orbital and suborbital frequencies over the last 450,000 years. Earth and Planetary Science Letters 212, 197-212.

Tzedakis, P.C., Frogley, M.R., Lawson, I.T., Preece, R.C., Cacho, I., de Abreu, L., 2004. Ecological thresholds and patterns of millennialscale climate variability: the response of vegetation in Greece during the last glacial period. Geology 32, 109-112.
Whiteman, C.D., 2000. Mountain Meteorology: Fundamentals and Applications. Oxford University Press, Oxford.

Willis, K., 1994. The vegetational history of the Balkans. Quaternary Science Reviews 13, 769-788.

Woodward, J.C., Macklin, M.G., Smith, G.R., 2004. Pleistocene glaciation in the mountains of Greece. In: Ehlers, J., Gibbard, P.L. (Eds.), Quaternary Glaciations — Extent and Chronology: Part I. Europe. Elsevier, pp. 155-173.

World Meteorological Organisation, 1998. 1961-1990 global climate normals. Electronic Resource. National Climatic Data Center, US, Asheville, NC. CD-ROM.

Yokoyama, Y., Lambeck, K., De Deckker, P., Johnston, P., Fifield, K., 2000. Timing of the Last Glacial Maximum from observed sealevel minima. Nature 406, 713-716. 